\title{
Short communication: Use of a mixture of sodium nitrite, sodium benzoate, and potassium sorbate in aerobically challenged silages
}

\author{
Martin Knicky and Rolf Spörndly ${ }^{1}$ \\ Department of Animal Nutrition, Swedish University of Agricultural Sciences (SLU), SE-750 07, Uppsala, Sweden
}

\begin{abstract}
Aerobic instability is still a common problem with many types of silages, particularly well-fermented silages. This study evaluated the effect of adding an additive mixture based on sodium nitrite, sodium benzoate, and potassium sorbate to a variety of crop materials on fermentation quality and aerobic stability of silages. Ensiling conditions were challenged by using a low packing density $\left(104 \pm 4.3 \mathrm{~kg}\right.$ of dry matter $\left./ \mathrm{m}^{3}\right)$ of forage and allowing air ingression into silos (at 14 and $7 \mathrm{~d}$ before the end of the storage, for $8 \mathrm{~h}$ per event). Additive-treated silages were found to have significantly lower $\mathrm{pH}$ and reduced formation of ammonia-N, 2.3-butanediol, and ethanol compared with untreated control silages. Yeast growth was significantly reduced by additive treatment in comparison with untreated control silage. Consequently, additive-treated silages were considerably more aerobically stable $(6.7 \mathrm{~d})$ than untreated control silages (0.5 d). Overall, adding $5 \mathrm{~mL} /$ $\mathrm{kg}$ of fresh crop of the additive based on sodium nitrite, sodium benzoate, and potassium sorbate reduced undesirable microorganisms in silages and thereby provided suitable ensiling conditions and prolonged aerobic stability, even under air-challenged laboratory ensiling conditions.
\end{abstract}

Key words: silage, additive, stability, yeast

\section{Short Communication}

A high degree of anaerobiosis is important for successful ensiling by lactic acid fermentation, which rapidly reduces the $\mathrm{pH}$ of the forage. Prolonged presence of oxygen may result in insufficient substrate for satisfactory lactate production due to extended respiratory activity of plants and prolonged activity of aerobic microorganisms, such as yeasts and molds. Insufficient elimination of these microorganisms during silage fermentation can result in unfavorable processes during the feed-out phase of the ensiling process (Jonsson and

Received January 10, 2015.

Accepted April 15, 2015.

${ }^{1}$ Corresponding author: rolf.sporndly@slu.se
Pahlow, 1984), when exposure of silage to air is inevitable. Aerobic deterioration degrades the nutritional value and hygiene quality of silages (Woolford, 1990). These problems can be avoided or reduced by using selective additives that promote good fermentation, improve aerobic stability, and reduce hygiene risks.

The antimicrobial properties of sodium nitrite, sodium benzoate, and potassium sorbate have been described by Woolford (1975) and have been tested in variety of combinations to improve forage conservation (Lättemäe and Lingvall, 1996; Lingvall and Lättemäe, 1999; Knicky and Lingvall, 2004). The latest additive mixture, based on a combination of $50 \mathrm{~g}$ of sodium nitrite $/ \mathrm{kg}, 200 \mathrm{~g}$ of sodium benzoate $/ \mathrm{kg}$, and $100 \mathrm{~g}$ of potassium benzoate $/ \mathrm{kg}$, is reported to have high efficiency for improving silage quality in both high- and low-DM silages (Knicky and Spörndly, 2009). Its efficiency in preventing the growth of undesirable microflora in silages has also been demonstrated for a large variety of crops (Knicky and Spörndly, 2011). However, these results have been obtained in routine ensiling conditions with properly consolidated contents and properly sealed silos. Unfortunately, these are not always the conditions under which silages are ensiled in practice. Punctures and other damage to the silo cover, as well as uneven forage consolidation in the silo, are common. Such ensiling conditions challenge a silage additive in fulfilling its intended purpose. Therefore, testing the efficiency of silage additives under difficult ensiling conditions, as recommended by Kwella et al. (1993), can provide a better picture of their potential. The objective of our study was to examine the efficiency of a silage additive mixture comprised of sodium benzoate, potassium sorbate, and sodium nitrite when applied to silages made from a wide range of different crops and under air-challenged ensiling conditions.

A total of 5 crops were used, all harvested in or near Uppsala (59 $\left.50^{\prime} 32^{\prime \prime} \mathrm{N}, 17^{\circ} 40^{\prime} 23^{\prime \prime} \mathrm{E}\right)$, Sweden. The harvesting conditions and botanical composition of these crops are presented in Table 1 . The crops were selected from local farms, where they were cultivated according to normal agricultural practices in Sweden. For the leys, this involved approximately 90 and $60 \mathrm{~kg}$ of $\mathrm{N} /$ ha as a mineral fertilizer to the first and second cut, 
Table 1. Composition and stage of development of harvested crops used for ensiling with and without an additive mixture of sodium benzoate, potassium sorbate, and sodium nitrite

\begin{tabular}{|c|c|c|c|c|}
\hline Crop & $\begin{array}{l}\text { Cut/ } \\
\text { DM, g/ } \mathrm{kg}^{1}\end{array}$ & Weather $^{2}$ & Type of crop & Maturity of main crop \\
\hline I & First cut $/ 340$ & $\begin{array}{l}\text { Mostly cloudy, } \\
69 \% \text { RH, } 8^{\circ} \mathrm{C}\end{array}$ & Whole crop maize (100\%) & Hard dough stage \\
\hline III & Third cut/180 & $\begin{array}{l}\text { Partly cloudy, } \\
86 \% \mathrm{RH}, 16^{\circ} \mathrm{C}\end{array}$ & $\begin{array}{l}\text { Red clover }(30 \%) \text {, timothy and meadow fescue } \\
(67 \%) \text {, weeds }\end{array}$ & $\begin{array}{l}\text { Vegetative-pre-bud, } \\
\text { Vegetative }\end{array}$ \\
\hline $\mathrm{V}$ & Third cut/260 & $\begin{array}{l}\text { Partly cloudy, } \\
87 \% \mathrm{RH}, 14^{\circ} \mathrm{C}\end{array}$ & Timothy and meadow fescue (85\%), red clover & $\begin{array}{l}\text { Vegetative, } \\
\text { Vegetative-pre-bud }\end{array}$ \\
\hline
\end{tabular}

${ }^{1} \mathrm{DM}$ at harvest.

${ }^{2}$ Average daily relative humidity (RH) and temperature.

respectively, and farmyard manure once a year in the autumn. For whole-crop maize, approximately $90 \mathrm{~kg}$ of $\mathrm{N} / \mathrm{ha}$ and $30 \mathrm{~kg}$ of $\mathrm{P} / \mathrm{ha}$ as a mineral fertilizer were applied at sowing, whereas farmyard manure was applied in the previous autumn. Samples from all crops except maize were collected manually using a scythe and chopped in a stationary cutter head to approximately 5 $\mathrm{cm}$ in particle length. The maize crop (I) was harvested using a Claas-Jaguar precision harvester $(\approx 1 \mathrm{~cm}$ chop length; Claas, Malmo, Sweden). Crops II, III, IV, and $\mathrm{V}$ were field-wilted for 2 to $4 \mathrm{~h}$ before chopping. After chopping, the forages were mixed and divided into 2 fractions of $3 \mathrm{~kg}$ of fresh matter $(\mathbf{F M})$ each.

One forage fraction was treated with the silage additive, a water solution containing $200 \mathrm{~g}$ of sodium benzoate $/ \mathrm{kg}, 100 \mathrm{~g}$ of potassium sorbate $/ \mathrm{kg}$, and $50 \mathrm{~g}$ of sodium nitrite $/ \mathrm{kg}$, at a rate of $5 \mathrm{~mL}$ of additive $/ \mathrm{kg}$ of FM. The silage additive was applied to the forage in plastic bags using a manual spray bottle and then the contents of the bag were mixed thoroughly. The second forage fraction was left untreated and served as a control. Forage from each fraction was then ensiled in 3 laboratory silos ( $\approx 510 \mathrm{~g}$ of FM per silo) with $1.7 \mathrm{~L}$ of volume and a fermentation lock fitted on the lid. Water was added to the fermentation lock to achieve airtight sealing immediately after filling the silos. The lid and lower part of the silos were equipped with air inlets with rubber stoppers to allow controlled air ingression by removing and replacing the rubber stoppers. This was performed twice during the storage period, 14 and $7 \mathrm{~d}$ before the end, for $8 \mathrm{~h}$ each time. The silos were stored at room temperature $\left(20-24^{\circ} \mathrm{C}\right)$ for $49 \mathrm{~d}$.

Two samples of chopped fresh crop (before additive application) were collected from each crop. The number of lactic acid bacteria, yeasts, and molds was used to describe the microbiological composition of the fresh crops. The spread-plate methods using Slanetz-Bartley agar (Merck KGaA, Darmstadt, Germany) and the pour-plate method using Rogosa agar (Merck KGaA) were used to determine lactic acid bacteria (Pahlow, 1990). Serial dilutions of silage samples were cultured aerobically at $25^{\circ} \mathrm{C}$ on malt extract agar supplemented with $0.12 M$ lactic acid $(50 \mathrm{~mL} / \mathrm{L})$ to determine yeast and mold counts. Chemical analyses comprised determination of DM, ash, CP, and water-soluble carbohydrate (WSC) concentration, as well as the buffering capacity of the harvested crops. The concentration of DM was analyzed in 2 steps. First, fresh samples weighing approximately $150 \mathrm{~g}$ were dried for $18 \mathrm{~h}$ in a ventilated oven at $65^{\circ} \mathrm{C}$ and milled through a $1.0-\mathrm{mm}$ sieve. Final DM concentration was achieved by drying the milled sample at $103^{\circ} \mathrm{C}$ for $5 \mathrm{~h}$. Concentration of ash was determined by combusting at $550^{\circ} \mathrm{C}$ for $3 \mathrm{~h}$ in a muffle furnace. The concentration of WSC was analyzed using an extract derived from dried silage samples $(\approx 2.5 \mathrm{~g})$, which were diluted with $250 \mathrm{~mL}$ of distilled water, boiled for 10 min, and drained through H-602 filter paper (Whatman GmbH, Dassel, Germany). Concentration of WSC was determined using enzyme-based acid hydrolysis (Larsson and Bengtsson, 1983). Concentration of CP was analyzed using the Kjeldahl technique with $\mathrm{Cu}$ as a catalyst (Bremner and Breitenbeck, 1983). Buffering capacity was determined according to the methods of McDonald and Henderson (1962).

The silos were weighed at the time of filling (d 0) and again at d 3, 10, 28, 42, and at the end of storage to determine weight losses. The weight losses were calculated by assuming the lost weight to be $\mathrm{CO}_{2}$ leaving the silo via the fermentation locks. It was further assumed that for each mole of $\mathrm{CO}_{2}, 1$ mol of $\mathrm{H}_{2} \mathrm{O}$ was produced. Hence, for each gram of weight decrease due to $\mathrm{CO}_{2}$, $0.44 \mathrm{~g}$ of the DM in the silo was transferred into water. Therefore, the DM loss was calculated as the decrease in weight of the silo multiplied by a factor of 1.44, expressed as grams per kilogram of DM. On the last day of storage period, the silo contents were emptied into 
a separate plastic bag, mixed thoroughly, and sampled. The spread-plate method was used to determine lactate-assimilating yeast and mold count in the silages. To determine lactate-assimilating yeast counts, serial dilutions of silage samples were cultured aerobically at $30{ }^{\circ} \mathrm{C}$ on agar-agar (Merck KGaA), supplemented with yeast nitrogen base, $0.12 M$ lactic acid, $\mathrm{NaOH}(2 \mathrm{~N}$, $30 \mathrm{~mL} / \mathrm{L})$, penicillin $\mathrm{G}(6 \mathrm{~mL} / \mathrm{L})$, and streptomycin sulfate $(6 \mathrm{~mL} / \mathrm{L})$.

Chemical analyses were used to determine the concentration of DM, pH, ammonia-N (ASN 50-01/92 in FIA system from FOSS-Tecator, 1992), concentration of fermentation acids (lactic, acetic, and butyric acid), ethanol, and 2.3-butanediol in silages. Content of DM was analyzed in the same way as with the fresh forage, with a constant correction for silage volatiles of 1.4 percentage unit added to the final calculation. This value is an in-house laboratory standard obtained through from a regression estimating the water content of silage samples based on the true water content measured by Karl Fischer titration of toluene distillates $\left(\mathrm{R}^{2}=0.99\right.$, $\mathrm{CV}=2.7, \mathrm{n}=410)$. Silage $\mathrm{pH}$ was determined using a pH electrode (654 pH-meter Methrom AG, Herisau, Switzerland) in the silage extract. Concentrations of fermentation acids, ethanol, and 2.3-butanediol were determined from silage juice using HPLC according to Andersson and Hedlund (1983). Aerobic stability in the silages was determined at the end of the storage period by measuring the temperature increase, assuming that this increase was caused by respiration by microorganisms and thereby indicated onset of aerobic deterioration in silage. The number of days it took for a silage to increase in temperature by $3^{\circ} \mathrm{C}$ was used to express aerobic stability (Honig, 1990). Silage temperature was measured in $1,300-\mathrm{mL}$ PVC tubes covered at the bottom with polyurethane fiber. Packing density was decided in relation to DM concentration according to the equation: filling weight $(\mathrm{g}$ of $\mathrm{FM})=[-205.57 \times \ln (\%$ $\mathrm{DM})]+1,061$, based on DLG (2006) recommendations. Tubes were placed in an insulating polystyrene block and kept at room temperature for 5 to $7 \mathrm{~d}$.

Statistical analyses were performed using the GLM procedure of the SAS computer package (SAS Institute, 1990). An ANOVA in a randomized complete block design, with crop as block, was used to evaluate the effect of silage additive treatment on silage quality. The mean of 3 treatment replicates for each crop was considered the experimental unit. When the calculated values of $F$ were significant, the $t$-test was used to interpret any significant differences between mean values at $P<0.05$.

The packing density of forages was $104 \pm 4.3 \mathrm{~kg}$ of $\mathrm{DM} / \mathrm{m}^{3}$. Analyses of the fresh crop material (Table 2) revealed a low concentration of WSC and buffering capacity, but a high microbial count in crop I in comparison with other crops. The fermentation quality of additive-treated silages and of untreated control silages from all experiments is shown in Table 3. Except for crop I, additive treatment was found to give significantly lower $\mathrm{pH}$ values at the end of storage and higher lactic acid concentration than control treatments $(P<$ 0.02 and $P<0.04$, respectively). The concentrations of ammonia-N $(P<0.01), 2.3$-butanediol $(P<0.04)$, and ethanol $(P<0.04)$ were significantly reduced in all additive treatments compared with untreated control treatments. Differences between treatments in formation of other fermentation products, such as acetic acid, butyric acid, and propionic acid, were found to be nonsignificant $(P>0.05)$. Microbiological analyses revealed a lower $(P<0.001)$ count of lactate assimilation yeasts in all additive treatments than in control treatments. Additive treatment significantly reduced $(P<$ 0.001-0.003) weight losses during the whole ensiling period (Figure 1) compared with control treatments. Assessment of the aerobic stability of the silages, based on temperature measurements, showed that it took significantly less time $(P<0.001)$ for untreated control silages to achieve a $3^{\circ} \mathrm{C}$ increase in temperature than additive-treated silages (Table 4). Moreover, the $\mathrm{pH}$ value in silage after the stability study was lower $(P<$ $0.001)$ in additive treatments than in untreated control treatments.

The effect of the additive on silage fermentation, and consequently on silage stability when air was introduced close to silo unloading, was also investigated. Fungi and yeasts in particular are considered the main causative microorganisms of aerobic deterioration of silage (Pahlow et al., 2003). Jonsson and Pahlow (1984) demonstrated that the group of acid-utilizing yeasts, in particular, is responsible for initiating aerobic spoilage of silages. This also appears to have been the case in the present study, as control silages contained considerably high counts of lactate-utilizing yeasts at silo opening and these silages had low aerobic stability and elevated silage $\mathrm{pH}$ value after the stability test. The results from the microbiological analyses of silages confirmed findings by Daniel et al. (1970) that silages which contain more than $10^{5}$ yeasts per gram of DM at the time of unloading tend to exhibit thermal instability. In contrast to control silages, the silages treated with the mixture of sodium benzoate, potassium sorbate, and sodium nitrite had low yeast counts and were aerobically stable during the whole stability test. Moreover, because of elimination of undesirable microorganisms by additive treatment, these silages revealed a better fermentation profile that resulted in low silage losses. These results confirm previous findings by Knicky and 
Table 2. Chemical and microbiological composition of fresh forages at ensiling $(n=2)$

\begin{tabular}{llrrrrr}
\hline & & \multicolumn{5}{c}{ Crop } \\
\cline { 3 - 7 } Parameter $^{1}$ & Unit $^{2}$ & I & II & III & IV & V \\
\hline DM & g/kg of FM & 343 & 342 & 364 & 346 & 350 \\
$\mathrm{Ash}$ & g/kg of DM & 69 & 119 & 111 & 102 & 86 \\
$\mathrm{CP}$ & g/kg of DM & 94 & 219 & 203 & 201 & 179 \\
$\mathrm{WSC}$ & g/kg of DM & 10 & 57 & 72 & 94 & 85 \\
$\mathrm{NO}_{3}$-N & g/kg of DM & 0.6 & 2.4 & 0.4 & 0.2 & 0.1 \\
Buffering capacity & g of LA/100 g of DM & 4.4 & 7.3 & 8.8 & 6.2 & 5.5 \\
LAB & log cfu/g of FM & 7.4 & 3.6 & 3.2 & 3.2 & 2.5 \\
Yeast & log cfu/g of FM & 6.0 & 3.8 & 3.5 & 2.5 & 4.1 \\
Mold & log cfu/g of FM & 4.2 & 3.1 & 3.2 & 3.8 & 3.4 \\
\hline
\end{tabular}

${ }^{1} \mathrm{WSC}=$ water-soluble carbohydrates; LAB = lactic acid bacteria.

${ }^{2} \mathrm{FM}=$ fresh matter; LA = lactic acid.

Table 3. Chemical and microbiological composition of silages treated with an additive mixture of sodium benzoate, potassium sorbate, and sodium nitrite and of untreated controls at the end of storage $(\mathrm{n}=5)$

\begin{tabular}{|c|c|c|c|c|c|}
\hline \multirow[b]{2}{*}{ Parameter } & \multirow[b]{2}{*}{ Unit $^{1}$} & \multicolumn{2}{|c|}{ Treatment } & \multirow[b]{2}{*}{ SEM } & \multirow[b]{2}{*}{$P$-value } \\
\hline & & Control & Additive & & \\
\hline $\mathrm{DM}$ & $\mathrm{g} / \mathrm{kg}$ & 343 & 347 & & \\
\hline $\mathrm{pH}$ & & $5.0^{\mathrm{a}}$ & $4.5^{\mathrm{b}}$ & 0.09 & 0.02 \\
\hline $\mathrm{NH}_{3}-\mathrm{N}^{2}$ & $\mathrm{~g} / \mathrm{kg} \mathrm{TN}$ & $89.5^{\mathrm{a}}$ & $47.8^{\mathrm{b}}$ & 5.57 & 0.01 \\
\hline Propionic acid & $\mathrm{g} / \mathrm{kg} \mathrm{DM}$ & $<0.5^{\mathrm{a}}$ & $<0.5^{\mathrm{a}}$ & - & 1.0 \\
\hline Lactic acid & $\mathrm{g} / \mathrm{kg} \mathrm{DM}$ & $26.3^{\mathrm{a}}$ & $41.6^{\mathrm{b}}$ & 3.56 & 0.04 \\
\hline Acetic acid & $\mathrm{g} / \mathrm{kg} \mathrm{DM}$ & $13.2^{\mathrm{a}}$ & $10.4^{\mathrm{a}}$ & 1.28 & 0.2 \\
\hline Butyric acid & $\mathrm{g} / \mathrm{kg} \mathrm{DM}$ & $<0.5^{\mathrm{a}}$ & $<0.5^{\mathrm{a}}$ & - & 1.0 \\
\hline 2.3-butanediol & $\mathrm{g} / \mathrm{kg} \mathrm{DM}$ & $12.1^{\mathrm{a}}$ & $0.8^{\mathrm{b}}$ & 2.62 & 0.04 \\
\hline Ethanol & $\mathrm{g} / \mathrm{kg} \mathrm{DM}$ & $10.1^{\mathrm{a}}$ & $3.8^{\mathrm{b}}$ & 1.45 & 0.04 \\
\hline Lactate-assimilating yeasts & $\log \mathrm{cfu} / \mathrm{g} F M$ & $6.7^{\mathrm{a}}$ & $<1.7^{\mathrm{b}}$ & 0.18 & 0.001 \\
\hline Molds & $\log \mathrm{cfu} / \mathrm{g} \mathrm{FM}$ & $<1.7^{\mathrm{a}}$ & $<1.7^{\mathrm{a}}$ & - & 1.0 \\
\hline
\end{tabular}

$\overline{\mathrm{a}, \mathrm{b}}$ Values within rows with different superscripts are significantly different $(P<0.05)$.

${ }^{1} \mathrm{FM}=$ fresh matter; $\mathrm{TN}=$ total nitrogen .

${ }^{2}$ Corrected for added $\mathrm{N}$ in the form of $\mathrm{NaNO}_{2}$ as it is converted into $\mathrm{NH}_{3}-\mathrm{N}$ (Knicky et al., 2014).

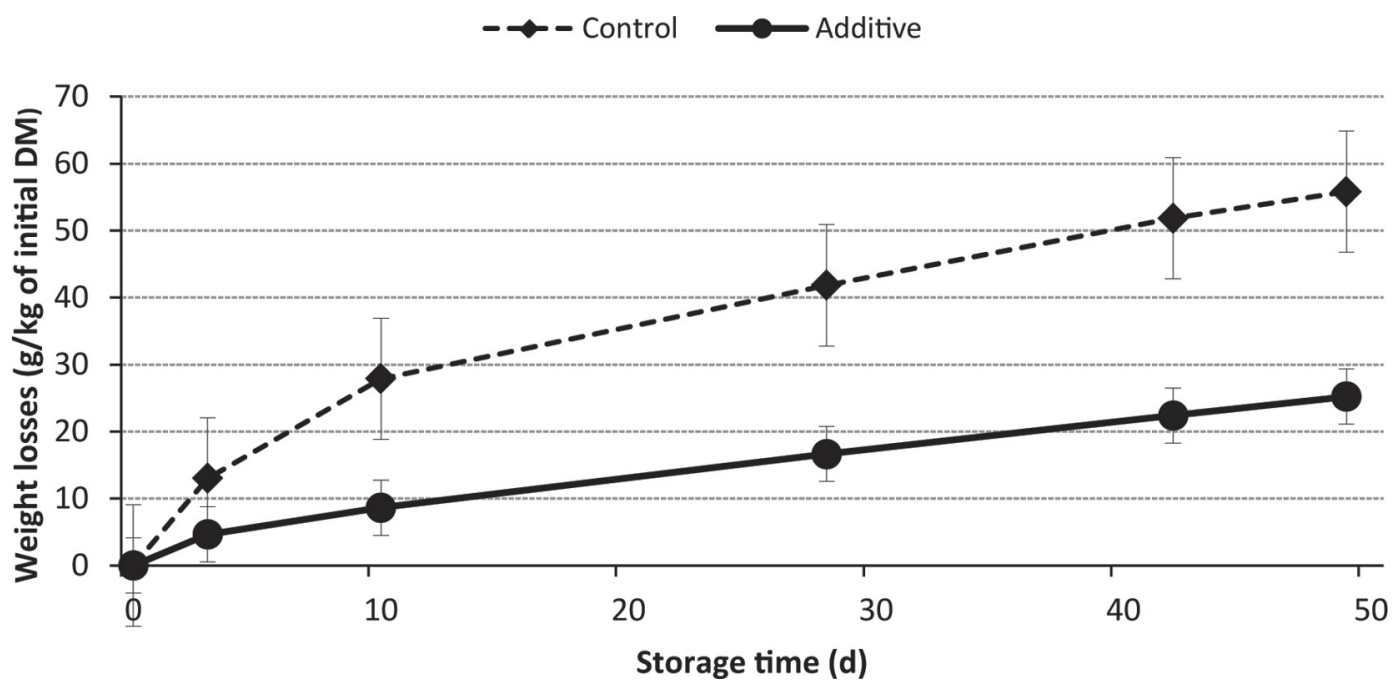

Figure 1. Weight loss during storage of silage treated with an additive mixture of sodium benzoate, potassium sorbate, and sodium nitrite and of untreated controls. Results are mean values and standard errors. 
Table 4. Storage stability of silages treated with an additive mixture of sodium benzoate, potassium sorbate, and sodium nitrite and of untreated controls, expressed as temperature increase $(\mathrm{n}=5$; ambient temperature $\left.=19.9^{\circ} \mathrm{C}\right)$

\begin{tabular}{|c|c|c|c|c|}
\hline Treatment & $\begin{array}{l}\text { Days until temperature } \\
\text { of aerated silage } \\
\text { increased by } 3^{\circ} \mathrm{C}\end{array}$ & $\begin{array}{l}\text { Maximum } \\
\text { temperature } \\
\left({ }^{\circ} \mathrm{C}\right)\end{array}$ & $\begin{array}{l}\text { Maximum } \\
\text { temperature } \\
\text { increase } \\
\left({ }^{\circ} \mathrm{C}\right)\end{array}$ & $\begin{array}{c}\mathrm{pH} \text { after } \\
\text { stability test }\end{array}$ \\
\hline Control & $0.5^{\mathrm{b}}$ & 36.8 & 18.7 & $7.5^{\mathrm{a}}$ \\
\hline Additive & $6.7^{\mathrm{a}}$ & 18.1 & 0.9 & $4.5^{\mathrm{b}}$ \\
\hline SEM & 0.13 & & & 0.29 \\
\hline$P$-value & 0.001 & & & 0.002 \\
\hline
\end{tabular}

${ }^{a, b}$ Values within columns with different superscripts are significantly different $(P<0.05)$.

Spörndly $(2009,2011)$, that the same additive mixture improved the quality of silages made from large variety of crops. The novel finding of the present study was that the additive effect was more pronounced when ensiling conditions were more challenging. The influence of ensiling conditions on the effects of silage additive on silage quality was also demonstrated by Knicky and Spörndly (2014) on samples from the same crops as used in the present study. However, due to the better ensiling conditions used in that study, there was no difference in aerobic stability between control and treated silages, whereas the challenged ensiling conditions in the present study caused differences between additivetreated and untreated silages.

The presence of fermentation products such as ethanol, ammonia-N, and 2.3-butanediol indicates undesirable processes. Although many bacteria can produce ethanol, it is suggested that high yeast counts predominantly contribute to the ethanol formation in silages (Pahlow et al., 2003). Elevated concentrations of ammonia- $\mathrm{N}$ in silages often indicate activity of clostridia (Weissbach and Haacker, 1988). However, clostridia seemed to not be a causative microorganism of ammonia- $\mathrm{N}$ formation in the present silages, as the main product of their activity, butyric acid (Weissbach and Haacker, 1988), was detected in negligible concentrations. It is more likely that enterobacteria (Pahlow et al., 2003) were responsible for the increased ammonia- $\mathrm{N}$ formation in the control silages. Evidence of their activity in silages is provided by the high concentration of 2.3-butanediol, one of the main products of enterobacterial activity in silages (McDonald et al., 1991). The survival of enterobacteria in the silages was probably affected by a high quantity of air being trapped in the silos due to the low packing density.

In conclusion, application of $5 \mathrm{~mL} / \mathrm{kg}$ of fresh crop of an additive mixture of sodium benzoate, potassium sorbate, and sodium nitrite reduced undesirable microorganisms in silages and thereby provided suitable ensiling conditions and prolonged aerobic stability, even under air-challenged ensiling conditions.

\section{ACKNOWLEDGMENTS}

The authors thank AB Hanson and Möhring (Halmstad, Sweden) for funding parts of the project.

\section{REFERENCES}

Andersson, R., and B. Hedlund. 1983. HPLC analysis of organic acids in lactic acid fermented vegetables. Z. Lebensm. Unters. Forsch. 176:440-443.

Bremner, J. M., and G. A. Breitenbeck. 1983. A simple method for determining ammonium in semi-micro Kjeldahl analysis of soil and plant materials using block digester. Commun. Soil Sci. Plant Anal. 14:905-913.

Daniel, P., H. Honig, F. Weise, and E. Zimmer. 1970. Wirkung von Propionsaure bei der Grünfuttersilierung. Das Wirtschaftseigene Futter 16:239-252.

DLG. 2006. DLG-Richtlinien für die Prüfung von Siliermitteln auf DLG-Gütezeichen-Fähigkeit (DLG guidelines for the test of silage additives for approval of DLG quality lables). DLG, DLG Commission for Silage Additives, Frankfurt, Germany.

FOSS-Tecator. 1992. Ammonia. Application Note ASN 50-01/92. Tecator, Höganäs, Sweden.

Honig, H. 1990. Evaluation of aerobic stability. Pages 76-82 in Proc. EUROBAC Conf., Aug. 1986. Grass and Forage Reports 3. Swedish Univ. of Agric. Sci., Uppsala, Sweden.

Jonsson, A., and G. Pahlow. 1984. Systematic classification and biochemical characterization of yeasts growing in grass silage inoculated with Lactobacillus cultures. Anim. Res. Develop. 20:7-12.

Knicky, M., and P. Lingvall. 2004. Ensiling of high wilted grass-clover mixture by use of different additives to improve the hygienic quality. Acta Agric. Scand. Ann. Anim. Sci. 54:197-205.

Knicky, M., and R. Spörndly. 2009. Sodium benzoate, potassium sorbate and sodium nitrite as silage additives. J. Sci. Food Agric. 89:2659-2667.

Knicky, M., and R. Spörndly. 2011. The ensiling capability of a mixture of sodium benzoate, potassium sorbate, and sodium nitrite. J. Dairy Sci. 94:824-831.

Knicky, M., and R. Spörndly. 2014. Silage additives-Assessment of their efficiency to improve aerobic stability of silages. Page 55-56 in Proc. 16th Int. Symp. Forage Conserv. Mendel Univ., Brno, Czech Republic.

Knicky, M., H.-G. Wiberg, F. Eide, and B. Gertzell. 2014. Dynamics of gas formation during ensilage. Pages 41-46 in Proc. 5th Nordic Feed Sci. Conf., Uppsala, Sweden. Dept. of Animal Nutrition and Management, Report 209. Swedish University of Agricultural Sciences, Uppsala, Sweden.

Kwella, M., K. Haaker, and B. Reuter. 1993. About investigations on the efficiency of silage additives. Pages $99-100$ in Proc. 10th Int. Conf. Silage Res. Dublin City Univ., Dublin, Ireland.

Larsson, K., and S. Bengtsson. 1983. Bestämning av lätt tillgängliga kolhydrater i växtmaterial. (Determination of non-structural car- 
bohydrates in plant material). Method description no. 22. National Laboratory for Agric. Chemistry, Uppsala, Sweden.

Lättemäe, P., and P. Lingvall. 1996. Effect of hexamine and sodium nitrite in combination with sodium benzoate and sodium propionate on fermentation and storage stability of wilted and long cut grass silage. Swed. J. Agric. Res. 26:135-146.

Lingvall, P., and P. Lättemäe. 1999. Influence of hexamine and sodium nitrite in combination with sodium benzoate and sodium propionate of fermentation and hygienic quality of wilted and long cut grass silage. J. Sci. Food Agric. 79:257-264.

McDonald, P., and A. R. Henderson. 1962. Buffering capacity of herbage samples as a factor in ensilage. J. Sci. Food Agric. 13:395-400.

McDonald, P., A. R. Henderson, and S. J. E. Heron. 1991. The Biochemistry of Silage. Chalcombe Publications, Marlow, Bucks, UK.

Pahlow, G. 1990. Untersuchung des epiphytischen Besatzes von Siliergut mit Milchsäurebakterien (Determination of epiphytic LAB in ensiled forage). Unpublished paper, Bundesforschungsanstalt für
Landwirtschaft (FAL), Institut für Grünland- und Futterpflanzenforschung, Braunschweig, Germany.

Pahlow, G., R. E. Muck, F. Driehuis, and S. J. W. H. Oude Elferink. 2003. Microbiology of ensiling. Page 50 in Silage Science and Technology. D. R. Buxton, R. E. Muck, and J. H. Harrison, ed. Am. Soc. Agron., Madison, WI.

SAS Institute. 1990. SAS/STAT User's Guide. Version 6. 4th ed. SAS Institute Inc., Cary, NC, USA.

Weissbach, F., and K. Haacker. 1988. On the causes of butyric acid fermentation in silages from whole crop cereals. Zeitschrift das Wirtschaftseigene Futter 3:88-99.

Woolford, M. K. 1975. Microbiological screening of food preservatives. Cold sterilants and specific antimicrobial agents as potential silage additives. J. Sci. Food Agric. 26:226-237.

Woolford, M. K. 1990. The detrimental effects of air on silage. J Appl. Bacteriol. 68:101-116. 